\section{Green Energy in Turkey}

Yeter Demir U* and Ufuk E

Giresun University Management, Ordu, Turkey

\begin{abstract}
As in the world, Turkey has also improved the renewable energy backed by the government as well as supporting institutions and organizations which build a project and do research on renewable energy.

Turkey is a pretty rich country due to both stream wealth and geographical position. Turkey being known countries as hydroelectric energy potential in the world, owing to the streams has an important position in terms of solar, wind and geothermal power, too.

This study aims to emphasize the importance of green energy in Turkey and create awareness the impacts of renewable energy on provinces having green energy potential, especially in an economic sense with green energy studies.
\end{abstract}

Keywords: Energy resources; Renewable energy; Green energy; Wind power; Solar power

\section{Introduction}

Energy is among the essentials of our lives. The nature is damaged by humankind in voluntarily so that the energy we use in our daily life is produced.

During green energy production and consumption, which is less harmful to the nature doesn't damage the environment. As in the world also in Turkey the tendency to green energy increased and consequently the private sector and public institutions are supported.

The aim of this study is to raise awareness revealing the renewable energy potential in Turkey.

\section{Green energy}

From past to present, notion of energy and sustainable energy resources are one of the important issues in the world. Rapidly the depletion of energy resources and insensibly the consumption of nonrenewable sources such as petrol, coal and atomic energy and all of this sources' effects on environment and atmosphere lead people to use renewable energy sources [1].

Renewable energy is usually defined as energy resources that can be mostly supplied above ground without needing any production process and do not come from fossil resources and are lower harm to environmental in contrast with conventional energy resources and can renew continuous kinesis and exist on earth at the ready [2].

In other words, renewable energy is a type of energy obtained from flow of energy that exists on natural periods. In contrast with conventional energy sources, renewable resources provide a lot of environmental profits [3].

When it is examined Turkey's energy profile, the concept of renewable energy sources has a highly important position. However, the use of renewable energy sources has quite low levels and these types of energy are not adequately interested. Particularly, the use of solar and wind power contribute substantially to Turkey's energy budget. The importance of plan, policies and strategy in order to benefit properly and healthfully from renewable energy resources gradually increases [4]. We can range the types of renewable energy producing energy in Turkey as solar energy, wind power, hydro-electric power and geothermal energy.

\section{Solar energy}

Solar power is electromagnetic energy that comes constitutively from the sun. Sun is a plasmic energy resource that consists of $92 \%$ hydrogen and $8 \%$ helium and a trace of other some atom and elements. Plasma is one of the states of matter that electrons separate from nuclear because of ultra-high temperature (Figure 1) [5].

According to studies made by General Directorate, renewable energy is low levels in Black-Sea and Marmara regions in Turkey. Sunshine durations in Black Sea region vary approximately maximum between 8 and 10 hours in June. Even if Solar Power that is 1.168 $\mathrm{KWh} / \mathrm{m}$ 2-years in Marmara region is under country average, it is a high rate in contrast with Europe. While sunshine durations in eastern Marmara region are average 10 hours, it can rise till 11 hours in Istanbul province. And also, the durations determine as 12 hours in Çanakkale and around.

According to a report studied by Ege University Institute of Energy, with regard to solar energy potential, Izmir is one of the most

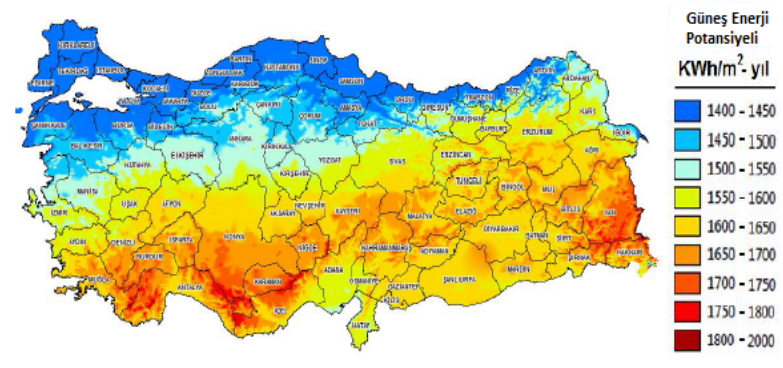

Figure 1: Turkey's solar energy potential.

*Corresponding author: Yeter Demir U, Giresun University Management, Ordu, Turkey, Tel: 904543101000; E-mail: dryeterdemir@gmail.com

Recieved September 29, 2015; Accepted November 29, 2015; Published December 05, 2015

Citation: Yeter Demir U, Ufuk E (2015) Green Energy in Turkey. J Entrepren Organiz Manag 4: 159. doi:10.4172/2169-026X.1000159

Copyright: $(2015$ Yeter Demir U, et al. This is an open-access article distributed under the terms of the Creative Commons Attribution License, which permits unrestricted use, distribution, and reproduction in any medium, provided the original author and source are credited. 
advantageous after the provinces in Mediterranean and southeastern Anatolia region [6]. While sunshine durations are till 12 hours in the region, utilization of durations from solar power rise [7].

Mediterranean that is one of the most advantageous regions of solar energy is determined as 13 hours. The region is at the southern, therefore, Mediterranean being one of the regions that solar radiation is the most intense is a crucial region for solar power. It is observed that is benefited from solar energy in the region, particularly in heating and greenhouse cultivation activities.

It is observed that both Mediterranean and southeastern Anatolia regions improve close rates. In contrast to the other regions, Mediterranean and southeastern Anatolia regions have markedly the advantage thus they separate easily. Consequently, it is anticipated that development policies about power generation produced from solar energy in Mediterranean region play an active role. According to the ministry of energy and natural resources' studies, it is understood that average monthly sunshine duration is more than Turkey's average sunshine durations for each one month. When it is examined across the provinces, it is understood that only Hatay's sunshine duration in month of July and August is less than Turkey's average. However, it is seen that Kahramanmaraş and Osmaniye have more sunshine durations for one each month according to Turkey's average [8].

According to a report made by Serhat Development Agency (SERKA), Agri and Igdir come into prominence in terms of solar power potential in the region. And also, it is stated that Both Agri with its solar radiation values and Igdir with its long sunshine duration are pretty convenient for solar power investments. According to reviews, Igdir's the average annual of Sunshine duration is 9.149. It is high than 7.49 which is Turkey's average annual sunshine duration. Moreover, it is determined that Igdir's sunshine duration in the summer month increases above 12 hours and Agri has annual average $1700 \mathrm{kWh}$ solar radiation values. Within this scope, the report says that it should be encouraged investments feasibility for power generation via photovoltaic panels and to be done feasibilities based upon greenhouse cultivations via solar power in these provinces and to popularize water heater system via solar energy throughout the region [9].

\section{Wind energy}

Wind power consists of replacing air mass that has different heats. $1-2 \%$ of Energy, which comes from sun to the world, converts into wind power. Taken into consideration Turkey's geographical features, it can be seen that Turkey is a rich country in terms of wind energy potential. In result of measurements made by meteorology, it is determined that southeastern Anatolia and the Marmara regions' wind power density is rather rich in contrast with other regions [10].

It is confirmed that Marmara region has maximum value with $3.29 \mathrm{~m} / \mathrm{sec}$ and $51 \mathrm{~W} / \mathrm{m}^{2}$ with regard to average annual wind speed and power density in 10 meter-high. On the other hand, Easftern Anatolia region has the lowest level with $2.12 \mathrm{~m} / \mathrm{sec}$ speed and 13.19 $\mathrm{W} / \mathrm{m}^{2}$ power densities. 11 certified wind farms that are above $50 \mathrm{~W} /$ $\mathrm{m}^{2}$ with not exceeding $20 \mathrm{~W} / \mathrm{m}^{2} 14$ items and 15 items between 30-40 $\mathrm{W} / \mathrm{m}^{2}$ have been activated in Turkey in 2014. Examined Wind power committee's power table, it is in evidence $41 \%$ of power to intensify in Aegean region while wind power committee in Aegean region says that $40 \%$ of power intensifies within İzmir provincial borders. This rate that corresponds to formed power 312, $4 \mathrm{MW}$, points out electric power production annual $826.500 .000 \mathrm{kWh}$. Moreover, wind electricity, acquired from Aegean region, is 2.000.000.000 kwh/year, and it is sufficient to supply İzmir's domestic-based electricity energy demand [6].

In consideration of velocity distribution of wind power that the cities have in Southeastern Anatolian region, it is observed that Hatay is the most advantageous one in terms of wind power in that region. As a result of studies, it is confirmed Hatay's formed wind energy power as $216 \mathrm{MW}$. Furthermore, it is determined that Gokcedag RES which has formed power $135 \mathrm{MW}$ in Osmaniye, is third big wind energy switchboard of Turkey after Balıkesir RES that has formed power 143 MW and Soma RES that has formed power $141 \mathrm{MW}$ [11].

Canakkale's wind energy potential comes into prominence due to location in Marmara region. It is confirmed the total to be established power capacity in Canakkale [12].

\section{Hydro-electric power}

Hydro-Electric switchboards (HPP) convert running water force into electricity. Water flow velocity or water flow arranges energy amount in running water. Running water which flows in a big river has vast amount of energy. Or, when water flows from a high point, it is acquired high amount of energy. In both ways, water, taken into the ducts or pipes, flows towards turbines, and it supplies to turn turbines that have column like a propeller for power generation. Turbines bases upon generators and they convert mechanical energy into power generation [8].

According to information taken from Energy Market Regulatory Authority, it can be seen in process of operation of HPP's energy power in Table 1. While Black-sea region is in the first place as region that produces more than energy $50 \mathrm{MW}$, Marmara region takes place last row. When we look at Sequences of HPP that produce low energy than $10 \mathrm{MW}$, Black-sea region ranks first. While Black-sea comes first in the number of HPP in the form of total operating, Mediterranean region comes second.

Statistical information in Table 2, that is acquired from Energy Market Regulatory Board shows that Black-sea region comes first in continuing HPP, while Marmara region comes second. When continuing HPP completes, 1656 HPP will have already begun energy generation.

There is among Turkey's 2023 targets to use overall potential for Hydroelectricity in energy generation. According to a report made by Turkish Electricity Transmission Corporation (TEIAS in Turkish), examined energy map in compliance with Turkey's formed hydraulic power, Although Hatay in Southeastern Anatolia region has under $100 \mathrm{MW}$ formed hydraulic energy power, it can be shown that Kahramanmaras ve Osmaniye have between $100 \mathrm{MW}$ and 1000 MW formed hydraulic energy power. Accompanied by actualizing

\begin{tabular}{|l|l|l|l|l|}
\hline & $\mathbf{3 1 0} \mathbf{M W}$ & $\mathbf{1 0 - 5 0} \mathbf{M W}$ & $\mathbf{2 5 0 M W}$ & Toplam \\
\hline Marmara Region & $\mathbf{2 1}$ & $\mathbf{8}$ & $\mathbf{2}$ & 31 \\
\hline Aegean Region & 13 & 9 & 4 & 26 \\
\hline Mediterranean Region & 41 & 30 & 17 & 88 \\
\hline Central Anatolia Region & 25 & 21 & 9 & 55 \\
\hline Black Sea Region & 57 & 64 & 28 & 149 \\
\hline Eastern Anatolia Region & 42 & 27 & 8 & 77 \\
\hline Southeastern Anatolia Region & 8 & 9 & 7 & 24 \\
\hline Total & 207 & 168 & 75 & 450 \\
\hline
\end{tabular}

Table 1: Distribution by licensed businesses in the region and hydroelectric power plants installed capacity. 


\begin{tabular}{|l|l|l|l|l|}
\hline & $\mathbf{S 1 0} \mathbf{M W}$ & $\mathbf{1 0 - 5 0} \mathbf{M W}$ & $\mathbf{2 5 0 M W}$ & Toplam \\
\hline Marmara Region & 168 & 83 & 86 & 337 \\
\hline Aegean Region & 75 & 100 & 61 & 236 \\
\hline Mediterranean Region & 88 & 67 & 48 & 203 \\
\hline Central Anatolia Region & 94 & 60 & 33 & 187 \\
\hline Black Sea Region & 186 & 157 & 53 & 396 \\
\hline Eastern Anatolia Region & 99 & 68 & 34 & 201 \\
\hline Southeastern Anatolia Region & 40 & 32 & 24 & 96 \\
\hline Total & 750 & 567 & 339 & 1656 \\
\hline
\end{tabular}

Table 2: Ongoing construction of the hydroelectric distribution by region and council of power.

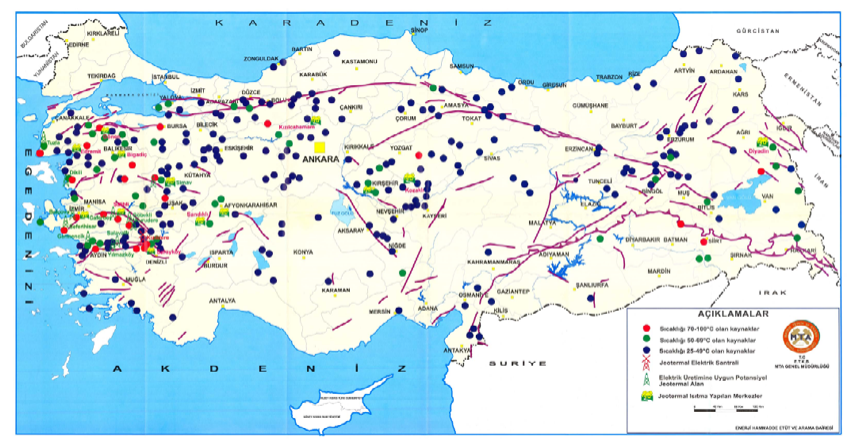

Figure 2: Turkey geothermal resource distribution and application map.

Hydraulic energy potential projects, it is anticipated that Hatay via HPP that produced the amount of electricity rises from $10 \mathrm{MW}$ to $46 \mathrm{MW}$ and Kahramanmaraş rises from $842 \mathrm{MW}$ to $1.402 \mathrm{MW}$ and Osmaniye rises from $774 \mathrm{MW}$ to $844 \mathrm{MW}$ [13].

\section{Geothermal energy}

It is understood that Turkey being seventh of the world in terms of geothermal energy potential can supply whole electricity demand till $5 \%$ and radiant density demand in heating till $30 \%$ [11].

Examined Figure 2, it is showed that geothermal energy resources have parallels with tectonic faults. Hence, it should be indicated that Aegean region is a crucial point in terms of geothermal energy. Particularly, Izmir has richest geothermal field of Turkey and Aegean region. Notably Balcova, the towns of Seferihisar, Cesme, Dikili, Bergama, Aliaga and Bayindir are important geothermal fields [6].

\section{Discussions}

Acar et al. [14], were determined the green energy to reduce environmental pollution, and as energy that the line technology and requirements will develop rapidly.

Ozkaya [15], when intending to say that the main features of the renewable energy are to reduce carbon dioxide emission and helpful to protect the environment, because it is domestic resource, it must reduce foreign dependency and make a contribution to increasing employment and also get support from public opinion widely.

Kumbur et al. [16], were determined as great importance energy resources the green energy resources due to the continuous and sustainable, and also were defined that environmental effects of green energy resource is more slightly than non-renewable energy resources.

\section{Conclusion}

It is tried to determine the regions' current situation and important sub-regionals that constitutes renewable energy resources in the studies made by Development agencies and other institutions. In continuation of the these studies, it should be formed healthy and reliable data sets belonging to renewable energy resources and supplied the data sets continuity and updating. For instance; the measurements of renewable energy sources should be locally and uninterruptedly done and recorded. It should be realistically reviewed the regions' gross, technique and economical potential according to emerging technologies [17].

- After it is created required awareness by way of being encouraged renewable energy investments, it will be supplied to get locals' electrical demand through a cheaper process and it will be a perfect example in Turkey those who will establish renewable energy coops. Moreover, it is considered that renewable energy switchboards building and operating period plays an important role in employment and economy.

\section{Refernces}

1. Kulekci OC (2009) Place of Geothermal Energy in The Content of Renewable Energy Sources and it's Importance for Turkey. Ankara University Journal of Environmental Science 1: 83-91.

2. Adiyaman C (2012) Turkiye'nin Yenilenebilir Enerji Politikalari Nigde University Institute of Social Sciences, Department of Public Administration, Nigde.

3. Ata R, Fatih O (2014) Manisa'nin Yenilenebilir Enerji Potansiyelinin Analizipotential Analysis of Renewable Energy Sources in Manisa. Celal Bayar University Journal of Science 1: 1-10.

4. Ozturel RZ, Ecevit A (2001)"Turkey's Strategic Planning Monitoring Policies Needed for Renewable Energy Sources and Their Social and Political Consequences". Renewable Energy Resources Symposium: 28-32, Istanbul.

5. Tuba YA, Gor HP (2013) Investment Project With Analytic Hierarchy Process Method. Journal of Suleyman Demirel University Faculty of Economics and Administrative Sciences18: 89-110.

6. Anonim I (2012) Izmir ili Yenilenebilir Enerji Sektor Analizi. Ege University Solar Energy Institute, Izmir.

7. Anonim I (2015) Maden Tetkik Ve Arama Genel Mudurlugu.

8. Anonim I (2015c) YEGM carried out by the Engineering Services Hydroelectric power plant projects.

9. Muhammad AY (2015) TRA2 Bolgesi Yesil Enerji Kaynaklari Sektor Raporu. SERKA, Yesil Enerji Potansiyelini Arastirdi.

10. Ata R, Rashid (2010) "Development of Geothermal and Wind Energy from Renewable Energy Sources and Environmental Assessment". CB Soma Vocational School of Technical Sciences Journal 2: 47-54.

11. Dogak A (2014) Yenilenebilir Enerji Raporu.

12. Anonim I (2015) Canakkale Anakkale ili Ruzgar Kaynak B Zgar Kaynak Bilgileri.

13. Ayranc E (2011)"TR42 East Marmara Region Renewable Energy Report". BRAND Development Agency, Kocaeli.

14. Acar E, Dogan A (2008) "Evaluation of Potential Environmental Effects", VII National Clean Energy Symposium, December 17-19: 675-682, Istanbul.

15. Ozkaya SY (2015) Yenilenebilir Enerji Kaynaklari.

16. Kumbur H, Ozer Z, Ozsoy HD, Hunter ED (2015) Turkiye'de Gelenekse ve Yenilenebilir Enerji Kaynaklarının Potansiyeli ve Cevresel Etkilerinin Karsilastırilmasi.

17. Anonim I (2015d) Gunes Enerjisi Potansitel Atlasi (GEPA). 